\title{
THE DEVELOPMENT OF THE COMBAINED PHARMACEUTICAL COMPOSITION WITH PLEIOTROPIC ACTIVITY BASED ON ORIGINAL SPERMOMODULATING SUBSTANCE*
}

\author{
S. P. Kustova, M. O. Boiko, V. M. Vacula, \\ T. V. Matvieieva, M. Ya. Kudria, N. Yu. Seliukova \\ SI «V. Danilevsky Institute for Endocrine Pathology Problems of NAMS of Ukraine», Kharkiv, Ukraine \\ bma.november@gmail.com
}

Nowadays, there are more than one million infertile couples in the different regions of Ukraine. Every fifth man is the main cause of this social problem. The idiopathic spermatogenesis disturbances represent the largest percentage of men's infertile etiological agents.

It is reported about association between liver diseases, such as alcohol cirrhosis, hepatitis $\mathrm{B}$ and $\mathrm{C}$ and disturbances of male sexual function. The disturbance of the liver functioning negatively impacts on the state of human organs and systems, causes their pathologies' development [1]. Liver diseases in men manifest by hypogonadism which is characterized by low free and general testosterone levels and increasing of the estrogens content that concerns the androgens deficiency development $[2,3]$. One of the basic mechanisms of the liver disease pathogenesis is disturbance of the proand antioxidant homeostasis $[4,5]$. In that regard, the most perspective medicines for male reproductive dysfunctions treatment are pharmaceutical compositions based on active ingredients similar to natural metabolic substances which have hepatoprotective effect and may normalize damaged spermatogenesis.

The original bioactive substance named «Kathiazin» (3- (4, 5-dihydrothiazol-2-yl) amid cis-1, 2, 2-trimethyl-cyclopentan 1,3-dicarbonic acid) was synthesized in SI «V. Danilevsky Institute for Endocrine Pathology Problems of NAMS of Ukraine» and demonstrated hepatoprotective and spermatogenesis modulating effects. The spermatogenesis stimulating effect of Kathiazin has been proved on the different models of pathospermia in rat mails in

* The study was carried out as a part of the research work of the Medical Chemistry Department of the SI «V. Danilevsky Institute for Endocrine Pathology Problems of NAMS of Ukraine» «The determination of the hepatoprotective properties of pharmaceutical composition based on kathiazin - spermatogenesis's stimulator» (State Registration Number 0116U004393).

Institution, which financed the research: NAMS of Ukraine.

The authors assume responsibility for the published work.

The authors guarantee absence of competing interests and their own financial interests when carrying out the research and writing the article.

The manuscript was received by the editorial staff 28.02.2019. 
doses of $0,6 \mathrm{mg} / \mathrm{kg}$ body weight and $6 \mathrm{mg} / \mathrm{kg}$ body weight. The therapeutic effect on the rat liver functioning disturbances has been determined on the models of acute and subchronic toxic, medicinal and combined hepatitis $[6,7]$. Kathiazin normalizes enzymatic liver's activity, improves its lipid synthesizing and detoxication functions, recovers glucose homeostasis, has anticoagulant effect, but doesn't demonstrate strong antioxidant properties [8, 9].

Therefore, the pharmacological properties of Kathiazin listed above, is the base for creation of the pharmaceutical composition (PhC) for spermatogenesis disturbances treatment and for normalization liver function activity.

The purpose of our investigation was the development of the pharmaceutical composition based on Kathiazin. The main task while creating the new medicines, is the choosing a kind of pharmaceutical dosage form, its composition according to the therapeutic aims. Taking into account our preliminary investigations and wide spread of the pharmaceutical capsules which allow to mix in one unit of dosage form substances with different physico-chemical properties, we suggested to elaborate capsules based on Kathiazin [10, 11].

The succinic acid (SA) has been added to the $\mathrm{PhC}$ with the aim of increasing the Kathiazin's hepatoprotective properties. SA is strong energetic substrate that takes part in the numerous biochemical redox processes in human organs and tissues including the conditions of the different pathologies [12-14].

\section{MATERIALS AND METHODS}

The objects of our investigation were Kathiazin substance, obtained according to [15] and excipients recommended by Ministry of Health of Ukraine [16] and experimental capsules masses.

The Kathiazin substance has been synthesized according to the [17] by using traditional organic chemistry methods for pharmaceutical technological trials.

Organoleptic characteristics such as condition, color, smell, texture of the active pharmaceutical ingredients (API), excipients and experimental capsules masses have visually controlled [18, a. 1.4, a. 2.3.4].

The pharmaceutical technological trials have been carried out according to the procedures recommended by State Pharmacopoeia of Ukraine, 2-nd edition [18 a. a. 2.9.1, 2.9.3, 2.9.7, 2.9.8, 2.9.16, 2.9.34, 2.9.35, 2.9.36].

The flowability of three samples of powder and powder compositions have been determined by measuring the powder mass flow rate through funnel with orifice's diameter $10 \pm 0,01 \mathrm{~mm}$. The flowability is measured in seconds and tenths of seconds related to the $100 \mathrm{~g}$ of sample.

Bulk density, compressibility index and Hausner ratio have been determined by measuring both the bulk volume and the tapped volume of a powder. The compressibility index and Hausner ratio may be calculated by using measured values for bulk density $\left(\rho_{\text {bulk }}\right)$ and tapped density $\left(\rho_{\text {tapped }}\right)$ as follows:

$$
\begin{gathered}
\text { Compressibility index }= \\
100 \times\left[\left(\rho_{\text {tapped }}-\rho_{\text {bulk }}\right) / \rho_{\text {tapped }}\right] ; \\
\text { Hausner ratio }=\left(\rho_{\text {tapped }} / \rho_{\text {bulk }}\right)
\end{gathered}
$$

The angle of repose is the constant, threedimensional angle, has been assumed by a cone-like pile of powder formed after its passing trough the funnel on the base of fixed diameter.

\section{RESULTS AND DISCUSSION}

The developing of the composition of $\mathrm{PhC}$ based on Kathiazin has been carried out with the consideration physical-chemical and pharmaceutical technological properties of the API powders and data from literature as to modern excipients suitable for capsules filling. For making appropriate volume of pharmaceutical dosage form sucrose, lactose, maize starch powder or pregelatinized maize starch and cellulose microcrystalline $(\mathrm{CM})$ have been used to be binders or blowing agents. Talc, different kinds of starch, colloidal silicon dioxide $\left(\right.$ Aerosil $\left.{ }^{\circledR}\right)$ and calcium or magnesium stearate may be added as glidant to improve powder flowability.

Auxiliary substances impacts both technological and biopharmaceutical properties of the medicines (absorbability, releasing of API, 
stability, etc). Scientific approach to choosing of the excipients based on numerous pharmaceutical technological tests provides high therapeutical effectiveness and minimal level of side effects [19].

The SA has been added to the $\mathrm{PhC}$ as an active pharmaceutical ingredient, but, according to the literature data, this substance has low permeability through cells membranes which decrease the effectiveness of medicines containing SA. Therefore, the glutaminic acid (GlA) has been introduced to $\mathrm{PhC}$ with the aim to improve absorbability of the SA [20].

The polyols (sugar alcohol) have been considered to be main excipients due to their benefits such as low insulinogenic ability. Among other polyol's benefits are their natural origin, low calorie content, inertness to other components and lower microbial contamination which causes the improvement of the microbiological stability of capsules. The polyols made by ROQETTE Company have been used in our investigations.
The Kathiazin powder particles have complicated surface area where static electric charge is accumulated that leads to some difficulties while technological process (sowing and mixing stages). This fact explains the necessity investigating of the magnesium stearate as glidant due to its antistatic and antiadhtsive properties.

The studying of the technological properties of the auxiliary substances used for the capsules masses has been carried out according to the State Pharmacopoeia of Ukraine procedures. The results are presented in table 1 .

The bulking properties of powders are the basic factors which determine such technological conditions as capacity rate, the using of specialized, standard or additional equipment. According to the bulk density values, powders may be divided into groups from very heavy $\left(>2.0 \mathrm{~g} / \mathrm{cm}^{3}\right)$ to light $\left(<0.6 \mathrm{~g} / \mathrm{cm}^{3}\right)$. The flow rate of powders during loading or reloading is evaluated by technological parameters - flowability and angle of repose, and may be described

Technological parameters of the active ingredients and excipients,

Table 1

$$
(X \pm S x), n=5
$$

\begin{tabular}{|c|c|c|c|c|c|}
\hline \multirow[b]{2}{*}{ Ingredient } & \multicolumn{5}{|c|}{ Parameter } \\
\hline & $\begin{array}{c}\text { Bulk } \\
\text { density, } \\
\text { g/sm }{ }^{3}\end{array}$ & $\begin{array}{c}\text { Angle } \\
\text { of repose, } \\
\text { degree }\end{array}$ & $\begin{array}{c}\text { Flowability, } \\
\text { g/sec }\end{array}$ & $\begin{array}{l}\text { Compres- } \\
\text { sibility } \\
\text { index, \% }\end{array}$ & $\begin{array}{l}\text { Hausner } \\
\text { ratio }\end{array}$ \\
\hline Kathiazin & $0.690 \pm 0.016$ & $35.8 \pm 1.0$ & $2.36 \pm 0.27$ & $11.2 \pm 0.8$ & $1.14 \pm 0.10$ \\
\hline SA & $0.842 \pm 0.010$ & $27.8 \pm 1.3$ & $9.90 \pm 0.90$ & $10.7 \pm 2.8$ & $0.82 \pm 0.02$ \\
\hline GlA & $0.350 \pm 0.002$ & $36.6 \pm 0.6$ & $3.15 \pm 0.14$ & $13.9 \pm 1.8$ & $0.71 \pm 0.02$ \\
\hline MC-101 & $0.330 \pm 0.010$ & $39.4 \pm 0.64$ & $1.65 \pm 0.02$ & $19.80 \pm 3.75$ & $1.25 \pm 0.06$ \\
\hline MC-102 & $0.300 \pm 0.004$ & $46.6 \pm 0.86$ & $1.44 \pm 0.02$ & $29.20 \pm 1.55$ & $1.41 \pm 0.03$ \\
\hline $\begin{array}{c}\text { Maltitiol } \\
\text { (Sweet Pearl } \\
\text { P 200) }\end{array}$ & $0.965 \pm 0.080$ & $28.2 \pm 1.1$ & $8.4 \pm 0.6$ & $10.1 \pm 2.6$ & $1.13 \pm 0.02$ \\
\hline Maize starch & $0.487 \pm 0.010$ & $50.6 \pm 0.6$ & $2.50 \pm 0.05$ & $12.0 \pm 0.9$ & $1.14 \pm 0.10$ \\
\hline $\begin{array}{c}\text { Mannitol } \\
\text { (Pearlitol } 160 \mathrm{C})\end{array}$ & $0.661 \pm 0.04$ & $47.2 \pm 0.3$ & absent & $25.2 \pm 0.6$ & $1.29 \pm 0.04$ \\
\hline Aerosil $®$ & $0.046 \pm 0.04$ & absent & absent & $61.7 \pm 1.3$ & $2.56 \pm 0.02$ \\
\hline $\begin{array}{l}\text { Pregelatini-zed } \\
\text { maize starch } \\
\text { (Lycatab PGS) }\end{array}$ & $0.644 \pm 0.02$ & $39.4 \pm 0.5$ & $4.95 \pm 0.60$ & $23.8 \pm 0.7$ & $1.31 \pm 0.02$ \\
\hline $\begin{array}{c}\text { Crosspovi-don- } \\
\text { XL }\end{array}$ & $0.323 \pm 0.07$ & $48.3 \pm 0.5$ & absent & $29.9 \pm 1.1$ & $1.43 \pm 0.04$ \\
\hline $\begin{array}{l}\text { Magnesium } \\
\text { stearate }\end{array}$ & $0.159 \pm 0.01$ & absent & absent & $44.4 \pm 0.3$ & $1.79 \pm 0.02$ \\
\hline
\end{tabular}


from excellent $\left(8.6-12 \mathrm{~g} / \mathrm{sec} ; 25^{\circ}-30^{\circ}\right)$ to very, very poor $\left(0.3-1 \mathrm{~g} / \mathrm{sec} ;>66^{\circ}\right)$. The determination of the compressibility index and Hausner ratio is the most useful, simple and quick procedure for predicting powder flowability. One of the methods of the measuring and evaluating the parameters listed above are described in «Methods» [18].

The figures represented in table 1 show that Kathiazin substance is considered to be light powder with good flowability according to the compressibility index and Hausner ratio. The other active pharmaceutical ingredient SA is light powder too, their flowability parameters are evaluating from fair to excellent.

The Glutaminic acid is considered to be light powder if evaluating its bulk density. The flowability of the glutaminic acid may be estimated from fair to good according to its measured and calculated compressibility index and Hausner ratio.

The maltitol demonstrated the average values of bulk density and good results of the compressibility index and Hausner ratio. The bulk density value of maize starch corresponded to light powder's substances and demonstrated good indices of flowability (compressibility index and Hausner ratio). The MC of both marks appertained to the light powders according to the bulk density values; flowability had values from poor to passable (passable values of the flowability demonstrated only MC - 101). The pregelatinized starch demonstrated average values of the bulk density, passable flowability according to the scale for compressibility index or Hausner ratio and fair flowability according to the angle of repose scale. As Kathiazin belongs to moister sensitive powders, an ability of pregelatinized starch and polyols to incorporate water from atmosphere during time has to be taken into consideration.

The mannitol (Pearlitol $160 \mathrm{C}$ ) demonstrated average values of bulk density, passable character of the flowability according to the scale for compressibility index and Hausner ratio and poor flowability as for angle of repose value that demand additional equipment and technological procedures of mixing or vibration.

Aerosil $^{\mathbb{}}$, Crosspovidon-XL and magnesium stearate belong to light powders as for bulk density and have very, very poor flowability according to the compressibility index and Hausner ratio values. It was impossible to measure the angle of repose and flowability of Aerosil ${ }^{\circledR}$ because its powder got dusty while testing. The flowability and angle of repose of magnesium stearate were not to be measured due to agglomeration of its powder.

Experimentally determined technological characteristics of Kathiazin and SA substances allow to use conventional auxiliary substances and does not demand additional technological procedures such as wet granulation. Taking into account data obtained, dry polyols, man-

The composition of the experimental capsules masses

Table 2

\begin{tabular}{|c|c|c|c|c|c|c|}
\hline \multirow{3}{*}{ Ingredient } & \multicolumn{6}{|c|}{ Content } \\
\hline & g & $\%$ & g & $\%$ & g & $\%$ \\
\hline & \multicolumn{2}{|c|}{ № 1} & \multicolumn{2}{|c|}{ № 2} & \multicolumn{2}{|c|}{ № 3} \\
\hline Kathiazin & 0,120 & 32,43 & 0,120 & 32,43 & 0,120 & 32,43 \\
\hline SA & 0,100 & 27,03 & 0,100 & 27,03 & 0,100 & 27,03 \\
\hline GlA & 0,100 & 27,03 & 0,100 & 27,03 & 0,100 & 27,03 \\
\hline $\begin{array}{c}\text { Maltitol (Sweet Pearl } \\
\text { P 200) }\end{array}$ & - & - & 0,048 & 12,97 & - & - \\
\hline Mannitol (Pearlitol 160 C) & - & - & & & 0,048 & 12,97 \\
\hline $\begin{array}{l}\text { Pregelatinized starch } \\
\text { (Lucatab PGS) }\end{array}$ & 0,048 & 12,97 & - & - & - & - \\
\hline $\begin{array}{l}\text { Silicon dioxide colloidal } \\
\left.\text { (Aerosil }^{\circledR}\right)\end{array}$ & 0,002 & 0,54 & 0,002 & 0,54 & 0,002 & 0,54 \\
\hline Average mass & 0,370 & 100,0 & 0,370 & 100,0 & 0,370 & 100,0 \\
\hline
\end{tabular}


Technological characteristics of the experimental capsules masses,

$(\mathrm{X} \pm \mathrm{Sx}), \mathrm{n}=6$

\begin{tabular}{c|c|c|c|c|c}
\hline \multirow{2}{*}{$\begin{array}{c}\text { Composi- } \\
\text { tion }\end{array}$} & $\begin{array}{c}\text { Bulk density, } \\
\text { g/sm }\end{array}$ & $\begin{array}{c}\text { Angle } \\
\text { of repose, } \\
\text { degree }\end{array}$ & $\begin{array}{c}\text { Flowability, } \\
\text { g/sec }\end{array}$ & $\begin{array}{c}\text { Compres- } \\
\text { sibility, \% }\end{array}$ & Hausner ratio \\
\hline № 1 & $0,674 \pm 0,020$ & $34,3 \pm 1,5$ & $3,20 \pm 0,21$ & $11,51 \pm 0,95$ & $1,14 \pm 0,033$ \\
\hline № 2 & $0,731 \pm 0,060$ & $36,8 \pm 1,1$ & $3,67 \pm 0,12$ & $12,10 \pm 1,01$ & $1,12 \pm 0,065$ \\
\hline № 3 & $0,533 \pm 0,006^{1)}$ & $30,4 \pm 0,4^{1)}$ & $5,98 \pm 0,11^{2)}$ & $6,32 \pm 0,19^{2)}$ & $0,85 \pm 0,004^{1)}$ \\
\hline
\end{tabular}

Note.

1) Significant difference compared to sample № 2 , $(\mathrm{P}<0,02)$;

2) Significant difference compared to sample № 2, $(\mathrm{P}<0,001)$.

nitol, pregelatinized maize starch and Aerosil ${ }^{\circledR}$ may be used as the excipients for the pharmaceutical composition.

During the developing the pharmaceutical composition based on Kathiazin in the solid gelatinous capsules from excipients listed above, the experimental samples of the $\mathrm{PhC}$ with different content of the auxiliary substances have been prepared. The average weight of each capsule's content is $0.370 \mathrm{~g}$.

According to the data of initial biological researches, the single human dose of Kathiazin is $120 \mathrm{mg}$, SA single dose in each unit of pharmaceutical dosage form is $100 \mathrm{mg}$, GlA single dose is equal to SA - $100 \mathrm{mg}$. The compositions of the experimental capsules masses are presented in table 2.

The samples of experimental capsules masses of the $\mathrm{PhC}$ based on Kathiazin have been pharmaco-technologically tested according to the State Pharmacopoeia's of Ukraine 2 edition requirements. The results of the investigation are presented in table 3 .

As we can see from table 3, capsules masses № 1 and № 2 demonstrated alike values of the technological characteristics in spite of differences in the formulations. Capsules mass № 3 which contains mannitol as filling, has shown the technological parameters much better than masses № 1 and № 2 .

The bulk density of all the experimental samples had average values $\left(1.1-0.6 \mathrm{~g} / \mathrm{sm}^{3}\right)$. The indices of flowability corresponded to good and excellent values (from $3.0 \mathrm{~g} / \mathrm{sec}$ to $6.5 \mathrm{~g} / \mathrm{sec}$ ). The angles of repose of the experimental capsules masses had values which characterized good flowability $\left(31-35^{\circ}\right)$. The compressibility indices and Hausner ratio of masses № 1 and № 2 corresponded to good flowability (11-15\% and 1.12-1.18) while parameters of sample № 3 were characterized excellent flowability of the mass (1-10 \% and 1.00-1/11).

Therefore, taking into account the results received, the most perspective capsules mass is composition № 3 which contains complete complex of active pharmaceutical ingredients, mannitol is to be basic excipients and silicon dioxide colloidal (Aerosil ${ }^{\circledR}$ ) is glidant.

\section{CONCLUSIONS}

The pharmaco-technological parameters (bulk density, flowability, compressibility and Hausner ratio) of the perspective active pharmaceutical ingredients of the pharmaceutical composition based on Kathiazin have been investigated.

The technological characteristics of capsules masses have been determined, the most perspective mass has been chosen for developing pharmaceutical dosage form based on Kathiazin.

The studying of different compositions of excipients has testified that chosen components allow to obtain formulations suitable for encapsulation using different industrial and laboratory equipment. 


\title{
REFERENCES
}

1. Babak OJa, Kolesnikova EV. Cirroz pecheni i ego oslozhnenija: monografija, Kiev, 2011: 576 p.

2. Sinclair M, Grossmann M, Gow PJ, Angus PW. $J$ Gastroenterol Hepatol 2015; 30: 244-251. doi: 10.1111/ jgh.12695.

3. Yurci A, Yucesoy M, Unluhizarci K, et al. Clin Res Hepatol Gastroenterol 2011; 35(12): 845-854. doi: 10.1016/ j.clinre.2011.09.005.

4. Li S, Tan H, Wang N, et al. Int J Mol Sci 2015; 16: 26087-26124. doi: 10.3390/ijms161125942.

5. Evdokimov VV, Korshunov MN, Korshunova ES, et al. Jeksperim i Klin Urologija 2010; 4: 38-42.

6. Kudrja MJa, Mel'nykivs'ka NV, Ustenko NV, et al. Probl Endokryn Patologii' 2015; 4: 53-60.

7. Gladkova AI, Sidorova IV, Jaremenko FG, Zolotuhina VN. Probl Endokryn Patologii’ 2012; 4: 102-108.

8. Patent 38711. Zasib dlja profilaktyky ta likuvannja patospermij.

9. Patent 104093. Zastosuvannja 3-(4,5-dygidrotiazol-2-il) amidu cys-1,2,2-trymetylcyklopentan-1,3-dykarbonovoi' kysloty dlja korekcii' porushen' funkcional'nogo stanu pechinky u samciv-shhuriv.

10. Kustova SP, Bojko MO. Ukr zhurn klin ta laborator medycyny 2012; 7(1): 79-82.
11. Chubka MB, Groshovyj TA, Vrons'ka LV. Farmacevtych Chasopys 2010; 2: 91-95.

12. Evgilevskij AA, Ryzhkova GF, Evgilevskaja EP, et al. Vestn Kurskoj Gos Akad 2013; 3: 68-78.

13. Suhanov DS, Petrov AJu, Romancov MG, et al. Fundam Issled 2011; 5: 169-168.

14. Simonjan EV, Shikova JuV. Uspehi Souremennogo Estestvoznanija 2014; 12(3): 231-235.

15. Patent 38/30. 3 (4,5-dygidrotiazol-2-il) amid cys-1,2, 2 -trymetylcyklopentan-1,3-dykarbonovoi' kysloty, shho stymuljuje spermatogenez.

16. Ljapunov M, Bezugla O, Solovjov O, et al. Standartyzacija farmacevtychnoi' produkcii': zbirnyk normatyvnyh dokumentiv, Kyi'v, 2012: 728 p.

17. Titce L, Ajher T. Preparativnaja organicheskaja himija, Moskva, 1999: $704 \mathrm{p}$.

18. Derzhavna Farmakopeja Ukrainy : v 3 t, 2 -e vyd, Harkiv, 2015;1: $1130 \mathrm{p}$.

19. Percev IM, Dmytrijevs'kyj DI, Rybachuk VD, et al. Dopomizhni rechovyny $\mathrm{v}$ tehnologii' likiv: vplyv na tehnologichni, spozhyvchi, ekonomichni harakterystyky i terapevtychnu efektyvnist': navch. posib, Harkiv, 2010: $600 \mathrm{p}$.

20. Salyga NO. Biologija tvaryn 2012; 14(1-2): 188-192.

\section{THE DEVELOPMENT OF THE COMBAINED PHARMACEUTICAL COMPOSITION WITH PLEIOTROPIC ACTIVITY BASED ON ORIGINAL SPERMOMODULATING SUBSTANCE}

\author{
S. P. Kustova, M. O. Boiko, V. M. Vacula, \\ T. V. Matvieieva, M. Ya. Kudria, N. Yu. Seliukova \\ SI «V. Danilevsky Institute for Endocrine Pathology Problems of NAMS of Ukraine», Kharkiv, Ukraine \\ bma.november@gmail.com
}

The article is devoted to the results of the theoretical and experimental investigations on the development of the optimal formulation of the pharmaceutical composition based on Kathiazin and Succinic acid in the solid gelatinous capsules. The glutaminic acid has been introduced into the pharmaceutical composition to improve the bioavailability of the succinic acid.

The content of active pharmaceutical substances has been determined. The single dose of Kathiazin is $120 \mathrm{mg}$, succinic and glutaminic acids - $100 \mathrm{mg}$. The kind of auxiliary substances used in modern pharmaceutical technology of the solid dosage forms has been grounded according to the literature data. The pharmacotechnological testing of the active pharmaceutical ingredients and auxiliary substances used in our research work has been carried out. The pharmaco-technological properties of the substances investigated according to the articles of State Pharmacopoeia of Ukraine (2 edition) have been estimated. The assessment of obtained data allowed to elaborate the composition of the experimental capsules masses. The flowability, bulk density, angle of repose, compressibility index and Hausner ratio of the mixtures created have been investigated due to requirements of the State Pharmacopoeia of Ukraine. On the base of scientific researching the most perspective pharmaceutical composition with excellent values of the flowability, angle of repose, bulk density, compressibility index and Hausner ratio has been chosen. This composition contains mannitol as the basic excipients for capsules mass. The silicon dioxide colloidal (Aerosil ${ }^{\circledR}$ ) is considered to be glidant substance which provides excellent flowability. As the result of the pharmaco-technological researches the qualitative and quantitative composition of the combined capsules based on Kathiazin and succinic acid has been developed. The testing of the pharmaco-technological parameters has proved the composition obtained is suitable to be encapsulated using different types of laboratory and industrial equipment. The elaborated combined dosage form based on Kathiazin and succinic acid may be proposed as a new original medicine with pleiotropic activity for treatment hepatitis of different origin in men with spermatogenesis disturbances.

Key words: Kathiazin, excipients, pharmaceutical composition, pharmaco-technological researches. 


\section{РОЗРОБКА СКЛАДУ КОМБІНОВАНОЇ ФАРМАЦЕВТИЧНОЇ КОМПОЗИЦІЇ З ПЛЕЙОТРОПНОЮ ДІЄЮ НА ОСНОВІ ОРИГІНАЛЬНОЇ СПЕРМОМОДУЛЮЮЧОЇ СПОЛУКИ}

Кустова С. П., Бойко М. О., Вакула В. М.,

Матвеева Т. В., Кудря М. Я., Селюкова Н. Ю.

ДУ «Інститут проблем ендокринної патологї̈ ім. В. Я. Данилевського НАМН Украйни»,

м. Харків, Україна

bma.november@gmail.com

В статті теоретично та експериментально обгрунтовано оптимальний склад фармацевтичної композиції у формі твердих желатинових капсул, де в якості основних діючих речовин виступають Катіазин та янтарна кислота, для покращення біодоступності останньої в організмі уведено глутамінову кислоту, основним наповнювачем обрано манітол, а сполукою, яка надає масі для капсулювання хорошої текучості, Аеросил ${ }^{\circledR}$. Тестування фармако-технологічних показників довело, що отримана суміш придатна для капсулювання на різних типах промислових і лабораторних капсульних машин.

Ключові слова: Катіазин, допоміжні речовини, склад фармацевтичної композиції, фармакотехнологічні дослідження.

\section{РАЗРАБОТКА СОСТАВА КОМБИНИРОВАННОЙ} ФАРМАЦЕВТИЧЕСКОЙ КОМПОЗИЦИИ З ПЛЕЙОТРОПНЫМ ЭФФЕКТОМ НА ОСНОВЕ ОРИГИНАЛЬНОЙ СПЕРМОМОДУЛИРУЮЩЕЙ СУБСТАНЦИИ

Кустова С. П., Бойко М. А., Вакула В. Н.,

Матвеева Т. В., Кудря М. Я., Селюкова Н. Ю.

ГУ "Институт проблем эндокринной патологии ил. В. Я. Данилевского НАМН Украинь»,

г. Харьков, Украина

bma.november@gmail.com

В статье теоретически и экспериментально обоснован оптимальный состав фрармацевтической композиции в форме твердых желатиновых капсул, в которых основными действующими веществами являются Катиазин и янтарная кислота. Для улучшения биодоступности последней введена глютаминовая кислота. Основным носителем был выбран маннитол, а субстанцией, придающей массе для капсулирования необходимую текучесть - Аэросил ${ }^{\circledR}$. Тестирование фрармако-технологических характеристик доказало, что полученная масса для наполнения капсул пригодна для использования на разных типах лабораторных и промышленных капсульных машин.

Ключевые слова: Катиазин, вспомогательные вещества, состав фрармацевтической композиции, фрармко-технологические исследования. 